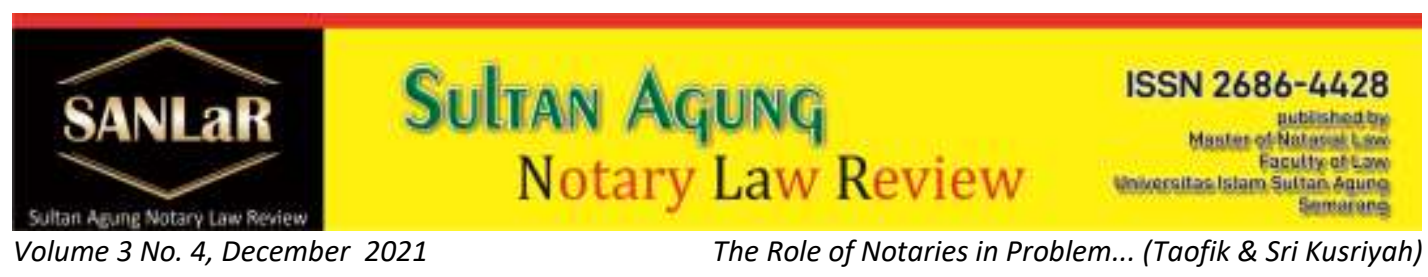

\title{
The Role of Notaries in Problem Solution of Inheritance Rights
}

\author{
Taofik $^{*}$ and Sri Kusriyah ${ }^{* *}$ \\ ${ }^{*}$ Faculty of Law, Universitas Islam Sultan Agung (UNISSULA) Semarang, E-mail: \\ taufikbasumbul5@gmail.com \\ ${ }^{* *}$ Faculty of Law, Universitas Islam Sultan Agung (UNISSULA) Semarang, E-mail: \\ kusriyah@unissula.ac.id
}

\begin{abstract}
The purpose of this study is to analyze and explain the role of a notary in solving inheritance rights problems. To analyze and explain the constraints and solutions to the role of a notary in solving inheritance rights problems. The method used by the researcher is Sociological Jurisdiction and specifications in this study are descriptive analytical. The sources and types of data in this study are primary data obtained from field studies with interviews. And secondary data obtained from literature studies related to the theory of justice and legal certainty. Based on the results of the study that The Role of Notaries in Settlement of Inheritance Rights Issues namely providing legal counseling, making the Deed of Separation and Distribution of Inheritance, namely: First, the Stage of Making the Deed of Declaration of Inheritance; Second, the Stage of Making SKHW; Third, the stages of making the deed of separation and distribution of inheritance. The solution is to have more control over inheritance law, whether civil, religious or customary. This is because inheritance law is one part of civil law as a whole and is the smallest part of family law which is closely related to the scope of human life. More professional in carrying out their duties. In this case, to guarantee certainty, order, and legal protection, authentic written evidence is needed regarding legal conditions, events, or actions carried out through certain positions.
\end{abstract}

Keywords: Role; Notary; Inheritance.

\section{Introduction}

Notary/PPAT is one of the institutions mentioned in the Civil Code whose authority is closely related to the making of authentic deeds and other 
authorities. Departing from the need for a perfect evidence (volledig bewijs) in accordance with the Burgelijke Wetboek (BW) or the Civil Code and the Herzien Inlandsch Reglement (HIR) or the Indonesian Civil Procedure Code, apart from material truth, Notaries also have important roles and duties and an honorable position. ${ }^{1}$

Notary is an office of trust. This implies that those who carry out their duties can be trusted and because the position of a Notary is a position of trust, so that the position of a Notary is a position of trust and those who carry out their duties can also be trusted, both of which support each other. Therefore, a Notary in carrying out his/her duties has the obligation to keep everything regarding the deed confidential in accordance with the oath/promise of office, unless the Law stipulates otherwise (Article 16 paragraph (1) letter e of Act No. 2 of 2014 concerning Amendments to Act No. 30 of 2004 concerning the Position of Notary). ${ }^{2}$

Of course, as stated by Komar Andasasmita, so that every Notary has quite broad and deep knowledge and skills so that it is the mainstay of the community in designing, compiling and making various authentic deeds, so that the language structure, technical juridical is neat, good and correct, because in addition to expertise It also requires honesty or sincerity and an objective nature or view. ${ }^{3}$

In the case of inheritance, Notaries are given certain roles and tasks. The separation of inheritance is carried out in a deed in advance of a Notary as confirmed in Article 1907 of the Civil Code. Which applies to this provision for the Chinese group, meaning that for native Indonesian citizens other provisions are applied outside the Civil Code.

Civil law that applies in Indonesia, including inheritance law is still diverse (pluralism), still does not have a legal unity that can be applied to all Indonesian citizens. The diversity of inheritance law can be seen from the division of inheritance law to inheritance law contained in the Civil Code, inheritance law contained in customary law, namely in the section on customary inheritance law and inheritance law contained in Islamic Inheritance Law, namely the provisions

\footnotetext{
${ }^{1}$ Andri Cahayadi, 2011, Peran Notaris Dalam Membantu Menyelesaikan Masalah Waris Melalui Pembuatan Keterangan Waris, Universitas Indonesia, Jakarta p. 82

${ }^{2}$ Abdul Ghofur Anshori, 2009, Lembaga Kenotariatan Indonesia Perspektif Hukum dan Etika, UII Press, Yogyakarta, p. 1.

${ }^{3}$ Komar Andasasmita, 1981, Notaris Dengan Sejarah, Peranan, Tugas Kewajiban, Rahasia Jabatannya, Sumur, Bandung, p. 14
} 
of inheritance law in Islamic jurisprudence called Mawaris or IImu Faraidh or the Compilation of Islamic Law (KHI). ${ }^{4}$

The distribution of inheritance using a notary deed is an alternative method of inheritance distribution in addition to using court institutions which are commonly used by Indonesian people in inheritance distribution. Similar to court decisions, the deed made by a notary is intended to explain the distribution of inheritance to anticipate problems that may arise in the future. Based on positive Indonesian law, there are several ways to determine the distribution of inheritance. The first, as already mentioned, is through a court decision, the second is through a notary through the distribution of the deed of separation and distribution of inheritance. Both have the same legal force so that if one family already has one or only uses one method, then the legal force is already strong. Both methods have equally strong legal force. Article 15 paragraph (1) of the UUJN explains that one of the powers of a Notary is to make a deed in general, with limitations as long as: (a) No exceptions are made to other officials stipulated by law. (b) The community of deeds that must be made or authorized to make authentic deeds regarding all acts, agreements, and provisions required by law or desired by the person concerned. (c) Regarding the legal subject (person or legal entity) for whose interest the deed was made or desired by the interested party. (d) Authority regarding the place, where the deed was made, this is in accordance with the domicile and area of office of the Notary. (e) Regarding the time of making the deed,

The objectives of this research are as follows:

a. To analyze and explain the role of a notary in solving inheritance rights problems.

b. To analyze and explain the constraints and solutions to the role of a notary in solving inheritance rights problems.

\section{Research Methods}

The approach method in this research is a sociological juridical approach. ${ }^{5}$ The nature of this research is included in the analytical descriptive research. ${ }^{6}$ The sources and types of data in this study are primary data obtained from field studies with interviews. And secondary data obtained from literature studies related to the theory of justice and legal certainty.

\footnotetext{
${ }^{4}$ H.A.Khisni, 2013, HukumWaris Islam, UNISSULA Press Semarang, p.21.

${ }^{5}$ Peter Mahmud Marzuki, 2005, Penelitian Hukum, Prenada Media Group, Jakarta, p. 29

${ }^{6}$ Soerjono Soekanto dan Sri mamudji, 2012, Penelitian hukum Normatif Suatu Tinjauan Singkat, Raja Grafindo, Jakarta, p.12
} 


\section{Results and Discussion}

\subsection{The Role of Notaries in Settlement of Inheritance Rights Issues}

To avoid legal conflicts in the certainty of inheritance distribution, what legal steps can be taken by a notary and interested parties to overcome this problem without going through a litigation process, but it is still within the legal corridor in the sense that it is not an unlawful act, becomes the focus of this research. ${ }^{7}$

The process of inheritance is a way how an heir acts to pass on or transfer the assets he will leave behind to the heirs when the heir is still alive and how the inheritance is passed on to control and use. In addition, it is also about how the implementation of the distribution of inheritance to the heirs after the heir dies.

The problem of wealth in society is a very vital factor. No doubt disputes that occur because of disagreements regarding the management of assets. Regarding property itself, it can be in the form of legal events, which we know as inheritance. There is a distribution of assets due to the death of the heir whose assets will fall to the rightful heirs. ${ }^{8}$

Islamic inheritance law in force in Indonesia. To ensure the orderliness of marriage for Muslims, every marriage must be recorded (article 5 paragraph 1 $\mathrm{KHI}) .{ }^{9}$ This social institution known as a "notariat" arises because of the need in the association of fellow human beings, which requires evidence for him regarding the civil law relationship that exists / or occurs between them, an institution and its adherents who are assigned by the general authority to where and if the law so requires or is desired by the community, make written evidence that has authentic strength. ${ }^{10}$

Notaries have existed in Indonesia since the Dutch colonial era. Governor General JPCoen considered that based on the needs of the residents and traders

\footnotetext{
${ }^{7}$ Noviana Dewi Harjanti, Akhmad Khisni, Peran Notaris Dalam Kepastian Bagian Warisan Untuk Anak Di Luar Nikah Yang Diakui Menurut Kitab Undang-Undang Hukum Perdata, Vol. 4 No. 4 December 2017, Jurnal Akta Unissula

8 Setya Qodar Al-Haolandi, Sukarmi, Peran Notaris Dalam Pembagian Waris Berdasarkan Hak Waris Barat Dengan Peran Pengadilan Agama Dalam Pembagian Waris Berdasarkan Hak Waris Islam, Vol 5 No 1 March 2018, Jurnal Akta Unissula

${ }^{9}$ Nabilla Ayu Suraya, Akhmad Khisni and Munsharif Abdul Chalim, Research on Inheritance for Children from Sirri Marriage Based on the Compilation of Islamic Law, Volume 2 No. 4, December 2020, Jurnal Sultan Agung Notary Law Review

${ }^{10}$ G.H.S. Lumban Tobing, 1992, Peraturan Jabatan Notaris, Erlangga, Jakarta, p. 2
} 
in the city of Jakarta, it was necessary to appoint a notary who at that time was called the notary public. In 1731 after the appointment of the sixth notary in Jakarta, the development of a notary began, because of the awareness of the need for a notary which finally began to occur in the appointment of a notary outside Jakarta by the local authorities. ${ }^{11}$

The role of a notary is very important in helping to create legal certainty and protection for the community, because a notary as a public official is authorized to make an authentic deed, as long as the making of an authentic deed is not reserved for other public officials. This legal certainty and protection can be seen through the authentic deed he made as perfect evidence in court. The evidence is perfect because the authentic deed has three powers of proof, namely the power of outward proof (uitwendige bewijsracht), the power of formal proof (formele bewijskracht) and the strength of material proof (materialele bewijskracht). Given that a notary is considered an honorable profession because it serves the interests of the general public. An honorable position places a burden and responsibility on every notary to maintain the prestige and honor of the notary profession. The prestige and honor of the notary profession in carrying out his duties as a public official must be maintained, because it requires rules that regulate, limit and serve as guidelines for notaries in carrying out their positions and behaving. ${ }^{12}$

Notaries carry out their duties, notaries must pay attention to the authorities, obligations and prohibitions listed in the UUJN and the notary code of ethics in providing services to people ${ }^{13}$ who need their services in the civil sector, especially in making authentic deeds. "The authority of a notary is a mandate of the UUJN that must be carried out in accordance with existing provisions, because without a clear and legitimate authority it is impossible for a notary to make an authentic deed. ${ }^{14}$

The Role of Notaries in Settlement of Inheritance Rights Issues namely providing legal counseling, making the Deed of Separation and Distribution of Inheritance, namely: First, the Stage of Making the Deed of Declaration of Inheritance; Second, the Stage of Making SKHW; Third, the stages of making the deed of

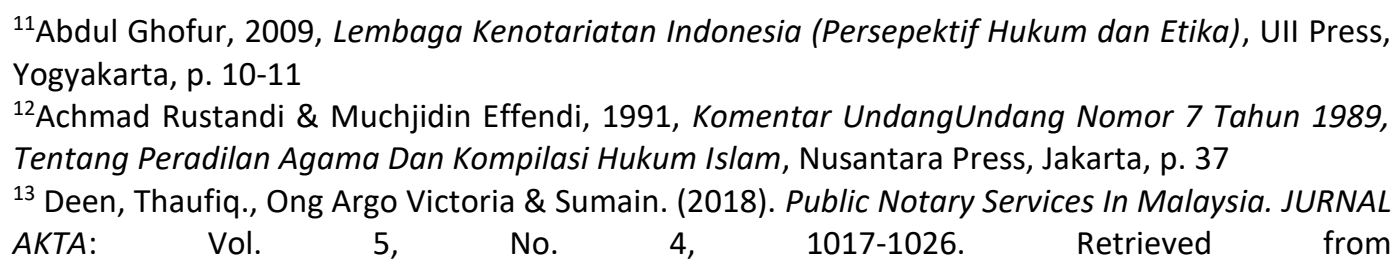
http://jurnal.unissula.ac.id/index.php/akta/article/view/4135

${ }^{14}$ Efendi Lutfi, 2004, Pokok-Pokok Hukum Administrasi, Bayumedia Publishing, Bandung, p. 7779. 
separation and distribution of inheritance. Before entering into the making of the Deed of Separation and Distribution of Inheritance, it must be preceded by the making of the two deeds mentioned first. Even so, in the process of making the Deed of Separation and Distribution of Inheritance, a notary requires documents that must be submitted to him by the heirs which include marriage certificates, death certificates, birth certificates of legal children, proof of citizenship.

According to the author, the role of a notary in solving inheritance rights problems analyzed using the theory of justice that justice is an inseparable part of the purpose of the law itself, in addition to legal certainty and expediency. This can be seen from the various legal problems that occur in Indonesia which are then outlined in several judges' decisions. This is stated in the philosophy of law that justice is the goal of law.

\subsection{Obstacles and Solutions to the Role of Notaries in Settlement of Inheritance Rights Issues}

Islamic inheritance law is an important expression of Islamic family law, it is half the knowledge possessed by humans as affirmed by the Prophet Muhammad SAW. Studying and studying Islamic inheritance law means studying half of the knowledge possessed by humans who have been and continue to live in the midst of Muslim society since the beginning of Islam to the Middle Ages, modern and contemporary times and in the future. ${ }^{15}$ From the beginning of history (origin) to the formation and development (change and development) in the contemporary era, the legacy of Islamic law shows dynamics and developments that are important to be studied and researched by observers of Islamic law. It is no coincidence that many observers have written and studied the development of Islamic inheritance law from various aspects. ${ }^{16}$

Notary Position as Official ${ }^{17}$ in society is still highly respected. Notary as an official, is a place for someone to get reliable advice. Everything he wrote and determined (the constants) was correct, he was a strong document maker in the legal process. Every society needs reliable, trustworthy (figure) information whose signature and stamp (stamp) provide strong guarantees and evidence, and impartial legal experts and advisors (onreukbaar or unimpeachable), who

\footnotetext{
${ }^{15}$ N. D. Anderson, 1991, Hukum Islam Di Dunia Modern, terj. Machnun Husein Amarpress, Surabaya, p. 66

${ }^{16}$ Ninuk Tri Welas, Comparative Study of Development between Islamic Inheritance Law According to Compilation of Islamic Law (KHI) \& Faroid Science, Volume 3 No. 1, March 2021, Sultan Agung Notary Law Review

${ }^{17}$ Soerjono Soekanto and Mamuji Sri, 2001, Penelitian Hukum Normatif suatu tinjauan singkat, Raja Grafindo Persada, Jakarta, p. 43
} 
keep their mouths shut and make a pact that can protect it in the days to come. ${ }^{18}$ The notary profession as part of the legal profession is considered a very noble and respectable profession, because the purpose of the legal profession is to uphold law and justice in people's lives. ${ }^{19}$ So as to make people believe in the notary profession, ${ }^{20}$ so that every aspect of life, whether social or business, requires the role of a notary in the relationship between people. ${ }^{21}$

For the sake of carrying out the duties of a good Notary, several principles are known, one of which is the principle of accuracy. Notaries in taking an action must be prepared and based on the applicable legal rules. Examining all evidence shown to the Notary and listening to statements or statements of the parties must be carried out as the basic material to be stated in the deed. This principle of accuracy is the application of Article 16 paragraph (1) letter a, among others, in carrying out the duties of his position, he is obliged to act carefully.

In essence, a Notary as a public official only establishes or relates or records in writing and authentically the legal actions of the parties concerned. Notaries are not in it, Notaries are outside parties, those who carry out legal actions are interested parties. The initiative to make a Notary deed or authentic deed rests with the parties. Therefore, a Notary deed or authentic deed does not guarantee that the parties "say the truth" but what is guaranteed by the authentic deed are the parties who "true to say" as contained in the deed. ${ }^{22}$

There is constraints on the role of a notary in solving inheritance rights problems namely (1) because they are not very familiar with inheritance law, so that notaries have difficulty in establishing legal events and pouring them into a deed (2) Another obstacle encountered is a dispute that arises when customary law is prioritized so that the inheritance deed is not heeded by the family parties. (3) In certain cases, there are also notaries who do not order the information and its truth, so that when making and ratifying the inheritance deed, it becomes a source of dispute in the future.

\footnotetext{
${ }^{18}$ Tan Thong Kie. 2007, Studi Notariat dan Serba-Serbi Praktek Notaris. Ichtiar Baru Van Hoeve. Jakarta, p. 449.

${ }^{19}$ Yulies Tiena Masriani, 2013, Kedudukan Hukum Akta-Akta Notaris Dalam Ekonomi Islam, Serat Acitya-Jurnal IImiah, p. 33

${ }^{20}$ Henny Saida Florida, 2014, Peran Notaris Dalam Pembuatan Akta Pendirian dan Akta Perubahan Anggaran Dasar Koperasi. Jurnal Saintech. p.61

${ }^{21}$ Detkri Badhiron, Umar Ma'ruf and Ngadino, Role of Notary in Change of Name of Limited Liability Company, Volume 3 No. 1, March 2021, Sultan Agung Notary Law Review

${ }^{22}$ Sjaifurrachman dan Habib Adjie, 2011, Aspek Pertanggungjawaban Notaris Dalam Pembuatan Akta, First Print., Mandar Maju, Bandung, p. 65
} 
Based on the description of the barriers the role of a notary in solving inheritance rights problems it can be seen that some suggestions that can be put forward as a form of solution include (1) To better master the inheritance law in civil, religious and customary terms. ${ }^{23}(2)$ more professional in carrying out their duties. In this case, to guarantee certainty, order, and legal protection, authentic written evidence is needed regarding legal conditions, events, or actions carried out through certain positions.

According to the author, problems and solutions to the role of a notary in solving inheritance rights problems in Indonesia Cirebon Regency was analyzed with the theory of legal certainty that the existence of general rules that make individuals know what actions are allowed and what cannot be done; Legal certainty for individuals from government arbitrariness because with the existence of general legal rules, individuals can know what the State may charge or do to individuals.

\section{Closing}

The Role of Notaries in Settlement of Inheritance Rights Issues namely providing legal counseling, making the Deed of Separation and Distribution of Inheritance, namely: First, the Stage of Making the Deed of Declaration of Inheritance; Second, the Stage of Making SKHW; Third, the stages of making the deed of separation and distribution of inheritance. Obstacles and solutions to the role of a notary in solving inheritance rights problems, namely: (1) because they are not very good at inheritance law, so that notaries have difficulty in establishing legal events and pouring them into a deed (2) Another obstacle encountered is a dispute that arises when customary law is prioritized so that the inheritance deed is not heeded by the family parties ( 3 ) In certain cases, there are also notaries who do not sort the information and its truth, so that when making and ratifying the inheritance deed, it becomes a source of disputes in the future. The solutions include (1) to have more control over inheritance law, whether civil, religious or customary. (2) more professional in carrying out their duties.

\section{References}

Journal:

[1] Detkri Badhiron, Umar Ma'ruf and Ngadino, Role of Notary in Change of Name of Limited Liability Company, Volume 3 No. 1, March 2021, Sultan Agung Notary Law Review

${ }^{23}$ Eman Suparman, 2007, Hukum Waris Indonesia, Refika Aditama, Bandung, p. 27 
[2] Deen, Thaufiq., Ong Argo Victoria \& Sumain. (2018). Public Notary Services In Malaysia. JURNAL AKTA: Vol. 5, No. 4, 1017-1026. Retrieved from http://jurnal.unissula.ac.id/index.php/akta/article/view/4135

[3] Henny Saida Florida, 2014, Peran Notaris Dalam Pembuatan Akta Pendirian \& Akta Perubahan Anggaran Dasar Koperasi. Jurnal Saintech

[4] Nabilla Ayu Suraya, Akhmad Khisni and Munsharif Abdul Chalim, Research on Inheritance for Children from Sirri Marriage Based on the Compilation of Islamic Law, Volume 2 No. 4, December 2020, Jurnal Sultan Agung Notary Law Review

[5] Ninuk Tri Welas, Comparative Study of Development between Islamic Inheritance Law According to Compilation of Islamic Law (KHI) \& Faroid Science, Volume 3 No. 1, March 2021, Sultan Agung Notary Law Review

[6] Noviana Dewi Harjanti, Akhmad Khisni, Peran Notaris Dalam Kepastian Bagian Warisan Untuk Anak Di Luar Nikah Yang Diakui Menurut Kitab Undang-Undang Hukum Perdata, Vol. 4 No. 4 December 2017, Jurnal Akta Unissula

[7] Setya Qodar Al-Haolandi, Sukarmi, Peran Notaris Dalam Pembagian Waris Berdasarkan Hak Waris Barat Dengan Peran Pengadilan Agama Dalam Pembagian Waris Berdasarkan Hak Waris Islam, Vol 5 No 1 March 2018, Jurnal Akta Unissula

[8] Yulies Tiena Masriani, 2013, Kedudukan Hukum Akta-Akta Notaris Dalam Ekonomi Islam, Serat Acitya-Jurnal IImiah

Books:

[1] A.Khisni, 2013, HukumWaris Islam, UNISSULA Press Semarang, Semarang,

[2] Abdul Ghofur Anshori, 2009, Lembaga Kenotariatan Indonesia Perspektif Hukum \& Etika, UII Press, Yogyakarta

[3] Achmad Rustandi \& Muchjidin Effendi, 1991, Komentar UndangUndang Nomor 7 Tahun 1989, Tentang Peradilan Agama \& Kompilasi Hukum Islam, Nusantara Press, Jakarta 
[4] Andri Cahayadi, 2011, Peran Notaris Dalam Membantu Menyelesaikan Masalah Waris Melalui Pembuatan Keterangan Waris, Universitas Indonesia, Jakarta

[5] Efendi Lutfi, 2004, Pokok-Pokok Hukum Administrasi, Bayumedia Publishing, Bandung

[6] Eman Suparman, 2007, Hukum Waris Indonesia, Refika Aditama, Bandung

[7] G.H.S. Lumban Tobing, 1992, Peraturan Jabatan Notaris, Erlangga, Jakarta

[8] Komar Andasasmita, 1981, Notaris Dengan Sejarah, Peranan, Tugas Kewajiban, Rahasia Jabatannya, Sumur, Bandung

[9] N. D. Anderson, 1991, Hukum Islam Di Dunia Modern, terj. Machnun Husein Amarpress, Surabaya

[10] Peter Mahmud Marzuki, 2005, Penelitian Hukum, Prenada Media Group, Jakarta,

[11] Sjaifurrachman \& Habib Adjie, 2011, Aspek Pertanggungjawaban Notaris Dalam Pembuatan Akta, First Print., Mandar Maju, Bandung, hlm. 65

[12] Soerjono Soekanto and Mamuji Sri, 2001, Penelitian Hukum Normatif suatu tinjauan singkat, Raja Grafindo Persada, Jakarta

[13] Soerjono Soekanto \& Sri mamudji, 2012, Penelitian hukum Normatif Suatu Tinjauan Singkat, Raja Grafindo, Jakarta

[14] Tan Thong Kie. 2007, Studi Notariat \& Serba-Serbi Praktek Notaris. Ichtiar Baru Van Hoeve. Jakarta 